\title{
Research on Internship Management of Hotel Management Specialty in Higher Vocational Colleges
}

\author{
Yan Gao \\ Huanggang Polytechnic College, Huanggang City, Hubei Province, China \\ 89067167@qq.com
}

Keywords: Internship; Management; Higher vocational; Hotel management

\begin{abstract}
Internship is an important part in the teaching process of higher vocational colleges. It is very important for the hotel management profession to do the internship work. However, there are endless problems in the process of internship, which lead to the contradiction between hotels, schools and students, which seriously affect the realization of the internship goal. This paper discusses the main problems in the process of internship, and discusses how to optimize the internship management of hotel management specialty in vocational colleges and universities in the light of the present situation of internship in hotel management in higher vocational colleges.
\end{abstract}

\section{Introduction}

Higher vocational and technical education is in accordance with the actual needs of social and economic development in order to enhance the professional quality of students as the goal for the social development to meet the needs of their talents. In the contemporary practice of higher vocational education, internship has been made in the implementation in more and more vocational colleges. However, in the actual operation process, the internship of vocational colleges has not fully played its due effect, in which students, schools, enterprises and the government have their own different responsibilities. In particular, vocational colleges, as the organizers, must strengthen the management of the internship.

The hotel industry is an industry with strong applicability. The goal of personnel training in higher vocational education is to cultivate high-quality skilled talents who meet the needs of the society. Therefore, internship is an important teaching link in vocational colleges. Compared to the school's daily teaching management, internship management is more difficult. The daily teaching management is carried out in a stable campus environment, while the internship management will face a variety of external factors, and many factors are beyond the control range in the internship management. [1]

\section{The problems in Internship of Hotel Management in Higher Vocational Colleges}

Students. Students' psychological expectations of internship are too high. Facing the upcoming cities and hotels, students are very excited. However, the hotel industry is a very hard industry, the demand for practical ability is very high, and people lack of hard-working spirit won't stay long in this business. Hotel professional students in the school cannot feel the real work environment of the hotel; internships can just make up for this deficiency. So most of the students are filled with hope to practice in hotels; imagining a very good internship process. And even some students believe that the specialty is hotel management, then the internship process should also be engaged in management positions, and the salary requirements are relatively high. But when they start the internship, only to find to do the waiter in the front line, the work content of bitter and tired, which is far from the previous imagination, a huge psychological gap caused by emotional instability. Students may often face customers' critical during the work, the crowding and cheating from older employees, as well as the criticism of superiors, those who can't bear will choose to give up internships.

Lack of stability during the Internship. Students usually work in the first-line of hotels, and it is not easy for students to change the position unless you have special reasons. Ranging from six 
months to one year of internship process, the students repeated the monotonous, boring and hard work content, during which tired heart, negative attitude, and resignation gradually breed; students are difficult to adhere to in the end.

Obstruction from parents. Now students are mostly only children, have much care at home, man and boy, never endure hardships, but now they have to serve others, wipe the table, mop the floor every day, many parents are distressed, and some parents do not even want their children to do the internship in hotels, which will affect their children's practical ability to enhance. Therefore, parents must use correct ideas to guide their offspring understanding occupation objectively and rationally. In particular, the hotel industry, not their prejudice that their children in the hotel service industry is to "serve" people, "wait on" people, lost parents face, feeling inferior, and some parents are not willing children to suffer, thinking at home never let children do any housework, and now they have to do all kinds of rough living in the hotel, this idea is wrong. Hotel management professional students must establish the correct professional values; the correct view of the hotel service industry, the hotel industry is only a kind of service industry. In fact, every one of us is living in the environment of serving and being served every day. [2]

Schools. Internship hotel selection problem. Choose good internship hotels are beneficial for students, schools, and hotels. However, the real high-end hotel service personnel requirements are high, most vocational students cannot meet the employment standards of the hotel. As a result, most students can only do the internships in the hotel with relatively low level, thus students won't be able to get high standards of training and mature sound management, and practice effect will be greatly reduced.

Internship instructors selection problem. Technician-teacher who has both theoretical knowledge and rich practical experience is the key to promote the effective practice. The technician-teacher can guarantee the guiding effect of the practice. However, in practice, the internship tutor is mostly young teachers, lack of work experience, are difficult to solve the problems, contradictions and emergencies in time and effectively in the process of internships. Practice guidance is often a mere formality and does not serve as an effective guide. [3]

Internship goal planning problems. Although many students get internship opportunities, but the satisfaction is not high after the internship. Some schools do not carry out a systematic design of student internships, just send the students to the hotel simply, a single practice positions, post technical content is low, the students become the hotel's cheap labor, resulting in practical teaching objectives cannot be achieved and internship effect be greatly reduced.

Hotels. The humanistic concern to interns. Some hotels do not establish a special internship management system, which lacks effective co-education to direct interns in the management process, which resulted in a poor effect practice. Some hotels treat interns with the same management style of social workers, ignoring the differences between trainees and social workers in many ways. Hotel management staff's blunt management style and serious attitude, making a lot of students are not used to this relationship, plus in the management process, a number of older employees put on the discretion of the interns, making it more difficult for many students to accept.

Internship reward problem. Compared practice with school's learning process, internship time per day is relatively long, rest time is relatively small, and time schedules contrast too much. Coupled with the lower salary interns, students do the same work with the hotel official staff, but wages are much lower than the formal staff, so that students are not willing to practice enthusiastically.

Internship training skills problem. The place where students can improve their skills is not much. The hotel claims to interns are treated equally, but interns because of their lack of work experience and the behavior of some old staff of bullying, it is difficult to achieve real fairness, a lot of interns in the hotel's jobs are passers, Chinese food waiters, Room attendants and other most tired post, so students think it cannot improve their professional skills. This also makes a lot of students are very disappointed at the hotel industry and do not want to engage in similar work after experiencing the internship. [4] 


\section{Optimization of External Environment for Internship Management of Hotel Management Specialty in Higher Vocational College}

Policy Incentives. School-enterprise cooperation is inseparable from the strong support of the government and industry management departments. Local governments should attach importance to the development of vocational schools, combined with local conditions, as much as possible to create a good environment for the vocational college students' internship.

The government promulgates relevant policies and regulations, such as the tax-free and tax-deductible policies of Canada, to encourage or support the enterprises in economic or policy, reduce the burden on enterprises, reduce the cost of enterprises and encourage enterprises to accept interns.

Presided over and Organized by the government, vocational schools, industry and enterprises could set up vocational education group, to strengthen the links between schools and enterprises, to build a resource platform.

Presided over by the government, joint industry associations, organize related enterprises to establish comprehensive training base, to achieve resource sharing and optimal allocation. [5]

Legal Protection. In order to protect the interests of students during internship, you can start from the following aspects:

To intensify the revision of the "Vocational Education Law of the People's Republic of China", to increase the protection of student internship rights related to the relevant regulations, but also learn from positive and effective absorption of local laws and regulations into the law.

Perfect supporting laws and regulations, clear the duties of educational administrative departments and labor administrative departments in the internship, so that they assume the management responsibility for the internship.

Strengthen the work of law enforcement, when students' internship rights and interests injured, we must be able to follow the law and have the law to effectively protect the rights and interests of students' internship.

Strengthen the publicity and supervision of laws and regulations; improve the legal awareness of the students, so that schools, internship units can consciously abide by laws and regulations. [6]

\section{Optimization of Internal Environment for Internship Management of Hotel Management Specialty in Higher Vocational College}

Pre-planning Stage. Choose the right hotel as a cooperative unit. Choosing the right internship hotel is not only good for students, but also for schools and hotels. To choose an internship hotel, first of all, students should have clear requirements for their internship goals, followed by the request to choose their own hotel, so that students can actually improve their ability through practice. The hotel can also get a access to the corresponding human edge in this internship process.

Develop a reasonable internship program. Schools need to conduct a full investigation before planning the internship, especially the quality requirements of the hotel staff. Only from the industry's demand for talent point of view, internship program can be consistent with the actual work requirements, students can be trained by the hotel Welcome and recognition. At the same time, the preparation of the internship program has to take full account of the school hotel management professional training program requirements, so that internships could become an important means to promote the teaching reform and achieve of training objectives. [7]

Mid-term Implementation Stage. When students enter the workplace, for a period of six months to one year internship, the supervision in this period will be the strong protection of effective implementation internships. The supervision of the internship period is carried out jointly by the school and the hotel. To this end, the school and the hotel to the two sides agreed to the regulatory system, the establishment of a scientific internship management system. Internship in the whole process, the school and the hotel to a reasonable division of labor on both sides, complement each other, so as to ensure the successful completion of the task, to achieve better practice effect. [8]

Late Evaluation Stage. After the end of internship, we need to evaluate the students' practice 
effect to help the next step in teaching. Completing the evaluation process of student's internship participation by school and hotel together, help strengthen the examination results of the real effectiveness. The internship instructor is responsible for school assessment while the hotel direct leadership be responsible for hotel assessment.

Assessment evaluation content must include all aspects in students' internship, in order to maximize the accuracy of the examination results. Specific assessment of content: professional ethics, work attendance, work efficiency, interpersonal relationships, internship report, internship weeks post, internship identification table. (Internship evaluation results can be divided into four sub-times: excellent, good, qualified, unqualified.) [9]

\section{Conclusions}

Internship management is not a simple addition of the elements, but the interaction of an organic whole, the elements of mutual promotion and mutual restraint. Only by fundamentally upgrading the various elements, we can realize the real optimization of internship management; cultivate high-quality skilled talents with social needs. [10]

\section{References}

[1] F. Yang: Discovery and Innovation for Teaching Practical System of Hotel Management (MS, Shanxi University, China, 2011).p.29

[2] L. J. Zhang: The Research on the Management of Post-Practice of High Vocational College Students under the Management by Objectives Theory (MS, Hunan Normal University, China, 2012).p.27

[3] F. L. Bi: Research on Practice Teaching System of Higher Vocational Hospitality Managements (MS, Liaoning Normal University, China, 2011).p.21

[4] J. F. Ma: Research on Substitution Internship Management at Higher Vocational Colleges in Qinhuangdao-Based on Some Majors (MS, Hebei Normal University of Science \& Technology, China, 2013).p.28

[5] K. F. Yao: Research on Current Situation, Issues and Countermeasures for Higher Vocational Students' In-post Practice-Taking Maanshan Technical College for Example (MS, Southwest University, China, 2012).p.45

[6] L. Xu: Research on Quality of Hotel Management Internship under the Higher Vocational Training Objectives (MS, Qingdao University, China, 2012).p.29

[7] Y. H. Cai: Study on Top-post Internship Program Management in Vocational Colleges (MS, China University of Geosciences (Beijing), China, 2011).p.29

[8] X. Niu: Research on Internship Management Pattern of Higher Vocational Institutions (MS, Shandong University, China, 2013).p.31

[9] L. Wang: Research on Higher Vocational College Students' Internship Process Management (MS, Nanjing Normal University, China, 2012).p.47

[10]H. W. Shang: Research on Graduation Practice Management of Higher Vocational Hotel Education (MS, Liaoning Normal University, China, 2010).p.39 